\begin{tabular}{|c|l|}
\hline Title & $\begin{array}{l}\text { Trilobodrilus itoi sp nov., with a Re Description of T. nipponicus (A nnelida: Dinophilidae) and a MolecularPhy logeny } \\
\text { of the Genus }\end{array}$ \\
\hline Author(s) & Kajihara, Hiroshi; Ikoma, Maho; Yamasaki, Hiroshi; Hiruta, Shimpei F. \\
\hline Citation & $\begin{array}{l}\text { Zoological science, 32(4), 405-417 } \\
\text { https://doi.org/40.2108/2s140251 }\end{array}$ \\
\hline Issue Date & 2015-08 \\
\hline Doc URL & http://hdl.handle.net/2115/62716 \\
\hline Type & article \\
\hline File Information & zs_32_p405.pdf \\
\hline
\end{tabular}

Instructions for use 


\title{
Trilobodrilus itoi sp. nov., with a Re-Description of T. nipponicus (Annelida: Dinophilidae) and a Molecular Phylogeny of the Genus
}

\author{
Hiroshi Kajihara $^{1 *}$, Maho Ikoma ${ }^{1}$, Hiroshi Yamasaki ${ }^{2}$, and Shimpei F. Hiruta ${ }^{1}$ \\ ${ }^{1}$ Faculty of Science, Hokkaido University, Sapporo 060-0810, Japan \\ ${ }^{2}$ Faculty of Science, University of the Ryukyus, Senbaru 1, Nishihara, \\ Nakagami, Okinawa 903-0213, Japan
}

\begin{abstract}
The marine interstitial annelid Trilobodrilus itoi sp. nov., the sixth member of the genus, is described on the basis of specimens collected intertidally at Ishikari Beach, Hokkaido, Japan; this is the second species in the genus described from the Pacific Rim. In addition, $T$. nipponicus Uchida and Okuda, 1943 is re-described based on fresh topotypic material from Akkeshi, Hokkaido, Japan. From both species, we determined sequences of the nuclear 18S and 28S rRNA genes, and the mitochondrial cytochrome $c$ oxidase subunit I (COI) gene. Molecular phylogenetic trees based on concatenated sequences of the three genes showed that $T$. itoi and $T$. nipponicus form a clade, which was the sister group to a clade containing the two European congeners $T$. axi Westheide, 1967 and $T$. heideri Remane, 1925. The Kimura two-parameter distance for COI was 22.5-22.7\% between $T$. itoi and $T$. nipponicus, comparable with interspecific values in other polychaete genera. We assessed the taxonomic utility of epidermal inclusions and found that the known six species can be classified into three groups.
\end{abstract}

Key words: North Pacific, marine invertebrates, archiannelid, mesopsammon, meiofauna, interstitial

\section{INTRODUCTION}

The dinophilid annelid genus Trilobodrilus Remane, 1925 comprises marine interstitial 'archiannelids' that reach approximately $2 \mathrm{~mm}$ in body length and lack typical polychaete features such as distinct body segmentation, parapodia, and chitinous chaetae. It currently contains five named species: T. heideri Remane, 1925 and T. axi Westheide, 1967 in European waters (e.g., Remane, 1925; Boaden, 1963; Westheide, 1967; Ax, 1968; Scharnofske, 1986); T. indicus Chandrasekhara Rao, 1973 from India (Chandrasekhara Rao, 1973); T. nipponicus Uchida and Okuda, 1943 from Japan (Uchida and Okuda, 1943), India (Chandrasekhara Rao and Ganapati, 1968), and the Pacific coast of the USA (Wieser, 1957); and T. hermaphroditus Riser, 1999 from the Atlantic coast of the USA (Riser, 1999). The hypothesis that these and other dinophilids have evolved from an ancestor most closely related to dorvilleid polychaetes in Eunicida (e.g., Westheide, 1987; Eibye-Jacobsen and Kristensen, 1994) was not supported by molecular phylogenetic analyses (Struck et al., 2002, 2005), and the sister taxon to Dinophilidae has not clearly been established (e.g., Rousset et al., 2007; Struck et al., 2008; Zrzavý et al., 2009). The family as currently diagnosed (Westheide, 1984) contains 16 species in three genera (Read, 2014). Dinophilids and other interstitial anne-

\footnotetext{
* Corresponding author. Tel. : : +81-11-706-2755;

Fax : +81-11-706-4851;

E-mail: kazi@mail.sci.hokudai.ac.jp
}

Supplemental material for this article is available online.

doi:10.2108/zs 140251 lid families, such as Diurodrilidae (Worsaae and Rouse, 2008; Golombek et al., 2013), Nerillidae (Worsaae et al., 2005), Protodrilidae (Bailey-Brock et al., 2010; Di Domenico et al., 2013; Martínez et al., 2013, 2014), and Saccocirridae (Di Domenico et al., 2014a, b, c) are important for understanding annelid evolution overall (Worsaae and Kristensen, 2005; Struck, 2006; Westheide, 2008) and the biogeography (Curini-Galletti et al., 2012) and macroevolutionary patterns (Rundell and Leander, 2010) of microscopic animals.

The Pacific species Trilobodrilus nipponicus needs redescription, as some of the morphological characters considered to be useful in distinguishing among congeners, e.g., the shape of 'epidermal inclusions' (see below), were not known for this species, nor were DNA sequence data available. Westheide (1967) pointed out that $T$. nipponicus is morphologically superficially similar to the European species $T$. heideri, and that a more detailed taxonomic description of the former is necessary to differentiate between them. While T. nipponicus has been reported from several localities distant from the type locality subsequent to the original description, insufficient original descriptions and lack of DNA data call into question previous species identifications of Trilobodrilus specimens worldwide (e.g., Rieger and Rieger, 1975).

Under light microscopy, specimens of Trilobodrilus show within the epidermis two types of small bodies up to $15 \mu \mathrm{m}$ long: (1) a mosaic or aggregation of droplets, and (2) an elongated, darker body with granular contents. The terminology for these small bodies has been inconsistent in the literature. Westheide (1967) originally used the term "Epidermiseinschlüsse" [epidermis inclusions] collectively to 
refer to both types, but called the aggregations of droplets "polygonale Felder" [polygonal fields] and the other, granular type "spindelförmige Drüsen" [spindle-shaped glands]. Chandrasekhara Rao (1973) did not use a collective term to refer to the two types, but called the former type "epidermal glands" and the latter "bacillary glands". Riser (1999) likewise did not use a collective term, but called the former type "epidermal inclusions" and the latter "spindle glands". Westheide (1967), who initially discovered epidermal inclusions in Trilobodrilus, noted differences in the inclusions between $T$. axi and $T$. heideri, which suggested the small bodies might provide useful taxonomic characters. Although the 'epidermis inclusions' sensu Westheide (1967) have been succinctly described in $T$. indicus (Chandrasekhara Rao, 1973) and T. hermaphroditus (Riser, 1999), their structure has not been explored in detail, nor has their taxonomic significance been rigorously assessed with statistical tests.

While Yamanishi (1983) listed 16 species of marine interstitial annelids reported from Japanese waters, representing 11 genera, these tiny worms remain understudied in this region. During the course of a faunal survey of marine interstitial animals around Hokkaido, northern Japan, we recognized two species of Trilobodrilus, one of which was referable to $T$. nipponicus, whereas the other turned out to be new to science. In this paper, we describe and illustrate these two species, and report the results of molecular phylogenetic analyses to infer their systematic position, making use of dinophilid sequences available in public databases. We also report intra- and interspecific variation in epidermis inclusions of the mosaic type (the "polygonale Felder" of Westheide [1967]), which we henceforth refer to as "epidermal inclusions' sensu Riser (1999), and discuss the taxonomic utility of variation in these structures.

\section{MATERIALS AND METHODS}

\section{Sampling and observation}

Sampling was conducted at two localities, Ishikari Beach and Akkeshi Bay, Hokkaido, northern Japan (Fig. 1). Specimens were extracted from intertidal sediment samples by freshwater shock followed by stirring and decantation: sediments were brought back to the laboratory and agitated briefly but intensively in tap water in a bucket; the suspension was passed through a Gwen's mermaid bra (Nybakken and Higgins, 2007) with a 32- $\mu \mathrm{m}$-mesh net; and the residue was immediately transferred to seawater to avoid rupture of the soft-bodied animals. Living worms were collected with a Pasteur pipette under a dissecting microscope and photographed with a Nikon D5200 digital camera attached to a Nikon SMZ 1500 microscope by adapters (NYPIXS2-3166, NY1S-FA, and NY1S-1501750, Micronet), with a pair of external strobe lights (Hikaru Komachi Di, Morris, Japan). For light microscopy, specimens were observed under an Olympus BX51 compound microscope after being anaesthetized in a $\mathrm{MgCl}_{2}$ solution isotonic to seawater and photographed with the same digital camera. For scanning electron microscopy (SEM), specimens were anaesthetized as just described and then fixed in formalin-seawater, dehydrated in an ethanol series, dried in a Hitachi HCP-2 $\mathrm{CO}_{2}$ critical-point drier, mounted on an aluminium stub, coated with gold in a JEOL JFC-1100 ion sputter coater, and observed with a Hitachi S-3000N scanning electron microscope at $15-\mathrm{kV}$ accelerating voltage. Measurements were taken from scaled digital images using ImageJ ver. 1.48 (Rasband, 1997-2014). Type and voucher material has been deposited in the Hokkaido University Museum (ZIHU), Sapporo, Japan.

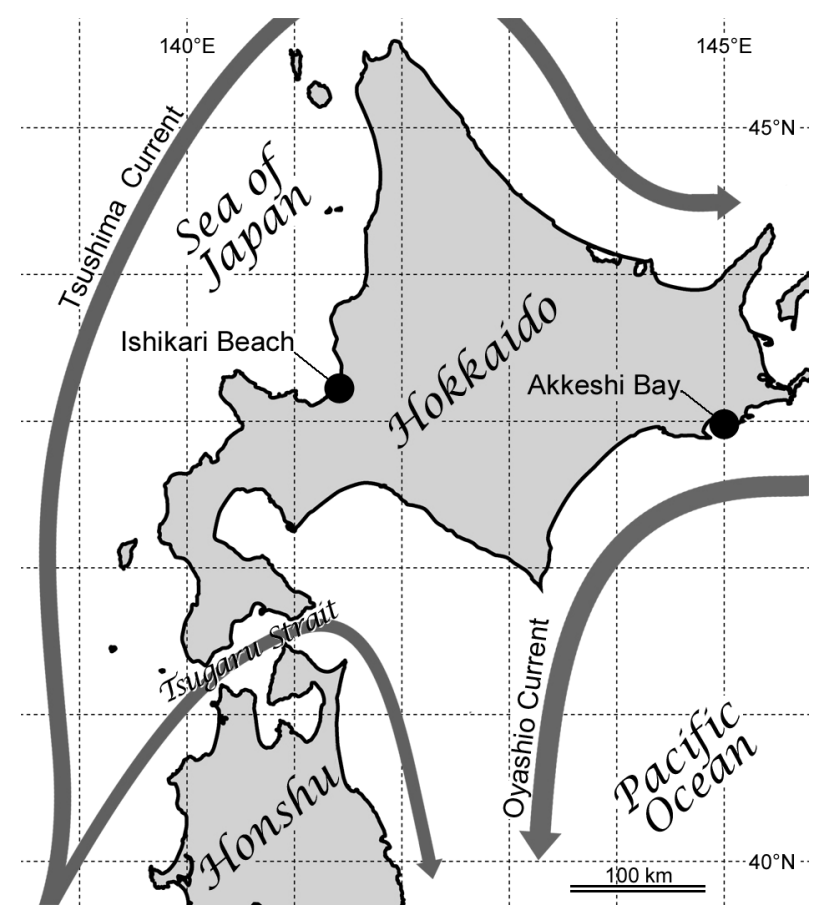

Fig. 1. Map of Hokkaido, northern Japan, showing the sampling sites and the surrounding ocean currents.

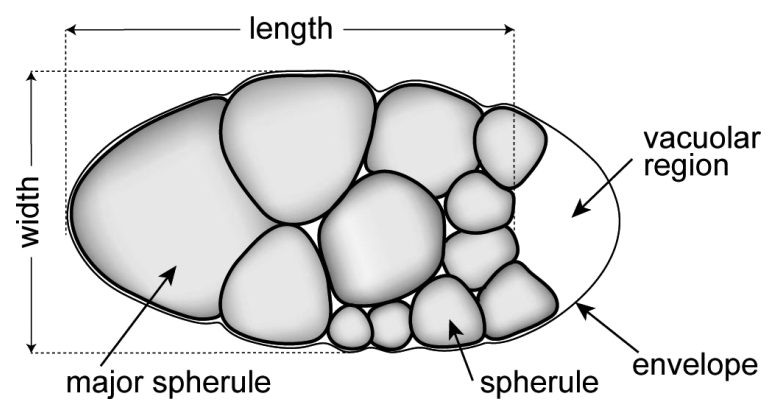

Fig. 2. Schematic drawing of an epidermal inclusion, defining length and width, and the terminology for the components.

\section{Analyses of epidermal inclusions}

Terminology and standard measurements pertaining to the mosaic-type epidermal inclusions treated here are given in Fig. 2. Each epidermal inclusion consists of an 'envelope' containing a number of 'spherules'. The envelope is embedded in the epidermis, but may connect with the exterior via a small opening. The spherule situated closest to the opening is usually (but not always) the largest; we call the largest spherule the 'major spherule', corresponding to the "cap-like unit" of Riser (1999). Within the envelope there may be a 'vacuolar region' that lacks spherules, usually at the end opposite the major spherule. Because the envelope is so thin and the spherules are packed so tightly within it, the envelope itself cannot be observed by light microscopy; its outline distinct from the spherules is evident only in the vacuolar region. In the drawings of Westheide (1967, fig. 5) and Chandrasekhara Rao (1973, figs. 5$6)$, the envelope is not illustrated at all; in the photographs of Westheide (1967, fig. 6) and Riser (1999, fig. 1), the outline of the envelope is unclear. In this paper, to compare the measurements from $T$. itoi and $T$. nipponicus with those from other species, the length of the epidermal inclusion is defined as the long axis of the aggregation of spherules, rather than of the envelope itself, and the 
width of the epidermal inclusion as the short axis of the spherule aggregation (Fig. 2).

To assess intraspecific variation in epidermal inclusions, the length and width of 11-26 epidermal inclusions were measured for each of five specimens of $T$. itoi sp. nov. Measurements were made from digital images, and differences in the variance and mean of the length-to-width ratio among the five specimens where examined by Bartlett's test and Tukey's HSD test, respectively. Interspecific variation in the epidermal inclusions was assessed in the same manner. For previously described species, lengths and widths were measured from figures in the published literature: Westheide (1967, figs. 5, 6) for $T$. axi $(n=13)$ and T. heideri $(n=15)$, Chandrasekhara Rao (1973, fig. 4) for T. indicus ( $n=2$ ), and Riser (1999, fig. 1) for $T$. hermaphroditus $(n=15)$. For $T$. nipponicus, 21 epidermal inclusions were measured from one specimen. Statistical tests were performed with $\mathrm{R}$ ver. 3.1.0 (R Core Team, 2014).

\section{DNA extraction, PCR amplification, and sequencing}

Total DNA was extracted by using a DNeasy Tissue Kit (Qiagen, USA). Fragments of the nuclear $18 \mathrm{~S}$ and $28 \mathrm{~S}$ rRNA genes (18S and 28S, respectively), and the mitochondrial cytochrome $c$ oxidase subunit I gene (COI), were amplified by polymerase chain reaction (PCR) with the primer pairs listed in Table 1. PCR conditions were $95^{\circ} \mathrm{C}$ for $1 \mathrm{~min}$; 35 cycles of $95^{\circ} \mathrm{C}$ for $30 \mathrm{sec}, 45^{\circ} \mathrm{C}$ for $90 \mathrm{sec}$, and $72^{\circ} \mathrm{C}$ for $3 \mathrm{~min}$ (90 sec for $\mathrm{COI}$ ); and $72^{\circ} \mathrm{C}$ for $7 \mathrm{~min}$. Sequences were determined with the primers listed in Table 1 by using a BigDye Terminator Kit ver. 3.1 (Life Technologies, USA) and a 3730 DNA analyzer (Life Technologies, USA).

For the new species, we also obtained longer sequences by next-generation sequencing (NGS). DNA concentration was measured with a NanoDrop 8000 Spectrophotometer (Thermo Fisher Scientific, USA). DNA (100 ng) was fragmented using an lon Xpress $^{\text {TM }}$ Plus Fragment gDNA Library Kit (Ion Torrent, USA). Fragments were ligated to barcode adapters using an Ion Xpress ${ }^{\mathrm{TM}}$ Barcode Adapters 33-48 Kit (Ion Torrent, USA). Using 2\% E-Gel ${ }^{\circledR}$
SizeSelect ${ }^{\mathrm{TM}}$ Agarose Gels (Invitrogen, USA), the resultant barcode library was subjected to size selection, targeting fragments $480 \mathrm{nt}$ long. After eight cycles of PCR amplification, the size-selected library was purified twice with AMPureXP (Beckman Coulter, USA), and the quantity of the library was determined with a High Sensitivity DNA Kit (Agilent Technologies, USA). Based on this library, emulsion-PCR-based beads were prepared by using an lon $\mathrm{PGM}^{\mathrm{TM}}$ Template OT2 $400 \mathrm{Kit}$ (Ion Torrent, USA). Sequencing was carried out with an lon Torrent $P \mathrm{PM}^{\mathrm{TM}}$ sequencer, using an Ion $314^{\mathrm{TM}}$ Chip ver. 2 (Ion Torrent, USA)/Ion PGM ${ }^{\mathrm{TM}}$ Sequencing 400 Kit (Ion Torrent, USA). Base calling was done with an Ion Torrent Server, with the output for each barcode in the form of binary sequence alignment/map (BAM)-format files. The adapter sequences in the BAM files were eliminated by using CLC Genomic Workbench ver. 7 (CLC Bio, USA); in addition, de novo assembly was performed with CLC Genomic Workbench ver. 7, yielding 3155 contigs; these were exported in FASTA format and subjected to similarity searches using BLAST+ ver. 2.2.29.

\section{Molecular phylogenetic analyses}

To infer phylogenetic relationships among species in Trilobodrilus, a maximum-likelihood (ML) analysis and Bayesian inference (BI) were carried out that included sequences from our two species and four species of dinophilids for which sequences were available in the public databases (Table 2). Because the sister taxon to Dinophilidae is uncertain (e.g., Rousset et al., 2007), outgroups were chosen to include taxa in seven polychaete families, with special emphasis on Dorvilleidae (cf. Eibye-Jacobsen and Kristensen, 1994). The sipunculan Sipunculus nudus Linnaeus, 1766 was used to root the trees (Kvist and Siddall, 2013; Weigert et al., 2014). Sequences were aligned gene by gene by using MUSCLE (Edgar, 2004) implemented in MEGA ver. 5.2 (Tamura et al., 2011) with the following settings: Gap Open = 400 ; Gap Extend = 0; Max Iterations = 8; Clustering Method (Iteration 1, 2) = neighbor joining; Clustering Method (Other Iterations) = neighbor joining; Min Diag Lengt

Table 1. List of primers used for amplification and sequencing, with original references.

\begin{tabular}{|c|c|c|c|c|c|}
\hline Gene & Primer name & Reaction* $^{*}$ & Primer sequence (in $5^{\prime}-3^{\prime}$ direction) & Direction & Source \\
\hline \multirow{8}{*}{$18 \mathrm{~S}$ rRNA } & K18SF & $\mathrm{A} / \mathrm{S}$ & GTCATATGCTTGTCTTAAAGATTAAGC & Forward & Present study \\
\hline & K18SR & $A / S$ & GGAAACCTTGTTACGACTTTTACTTCA & Reverse & Present study \\
\hline & $\mathrm{F} 2$ & S & CCTGAGAAACGGCTRCCACAT & Forward & Yamaguchi and Endo (2003) \\
\hline & F3 & $S$ & GYGRTCAGATACCRCCSTAGTT & Forward & Yamaguchi and Endo (2003) \\
\hline & F4 & S & GGTCTGTGATGCCCTYAGATGT & Forward & Yamaguchi and Endo (2003) \\
\hline & R6 & $S$ & TYTCTCRKGCTBCCTCTCC & Reverse & Yamaguchi and Endo (2003) \\
\hline & $\mathrm{R} 7$ & $S$ & GYYARAACTAGGGCGGTATCTG & Reverse & Yamaguchi and Endo (2003) \\
\hline & R8 & S & ACATCTRAGGGCATCACAGACC & Reverse & Yamaguchi and Endo (2003) \\
\hline \multirow{14}{*}{$28 \mathrm{~S}$ rRNA } & D1F & $A / S$ & GGGACTACCCCCTGAATTTAAGCAT & Forward & Park and Ó Foighil (2000) \\
\hline & $28 \mathrm{Sb}$ & $A / S$ & TCGGAAGGAACCAGCTAC & Reverse & Whiting et al. (1997) \\
\hline & 28S-01 & $A / S$ & GACTACCCCCTGAATTTAAGCAT & Forward & Kim et al. (2000) \\
\hline & $28 \mathrm{Sr}$ & $A / S$ & ACACACTCCTTAGCGGA & Reverse & Luan et al. (2005) \\
\hline & $28 S f$ & $A / S$ & TGGGACCCGAAAGATGGTG & Forward & Luan et al. (2005) \\
\hline & 28S-3KR & $A / S$ & CCAATCCTTTTCCCGAAGTT & Reverse & Yamasaki et al. (2013) \\
\hline & $28 \mathrm{~S}-2 \mathrm{KF}$ & $A / S$ & TTGGAATCCGCTAAGGAGTG & Forward & Yamasaki et al. (2013) \\
\hline & $28 \mathrm{jj}-3^{\prime}$ & $A / S$ & AGTAGGGTAAAACTAACCT & Reverse & Palumbi (1996) \\
\hline & 28S-n05R & $\mathrm{S}$ & CTCACGGTACTTGTTCGCTAT & Reverse & Yamasaki et al. (2013) \\
\hline & 28SR-01 & S & GACTCCTTGGTCCGTGTTTCAAG & Reverse & Kim et al. (2000) \\
\hline & $28 S-15 R$ & S & CGATTAGTCTTTCGCCCCTA & Reverse & Yamasaki et al. (2013) \\
\hline & $28 S-3 K F$ & S & AGGTGAACAGCCTCTAGTCG & Forward & Yamasaki et al. (2013) \\
\hline & $28 v-5^{\prime}$ & S & AAGGTAGCCAAATGCCTCATC & Forward & Palumbi (1996) \\
\hline & $28 \mathrm{~S}-42 \mathrm{~F}$ & S & GAGTTTGACTGGGGCGGTA & Forward & Yamasaki et al. (2013) \\
\hline \multirow{2}{*}{$\mathrm{COI}$} & LCO1490 & $\mathrm{A} / \mathrm{S}$ & GGTCAACAAATCATAAAGATATTGG & Forward & Folmer et al. (1994) \\
\hline & $\mathrm{HCO} 2198$ & $\mathrm{~A} / \mathrm{S}$ & TAAACTTCAGGGTGACCAAAAAATCA & Reverse & Folmer et al. (1994) \\
\hline
\end{tabular}

${ }^{*} \mathrm{~A}, \mathrm{PCR}$ amplification; S, cycle sequencing 
Table 2. List of species included in the phylogenetic analysis, with public database accession numbers.

\begin{tabular}{|c|c|c|c|c|}
\hline \multirow{2}{*}{ Taxa } & \multicolumn{3}{|c|}{ Markers } & \multirow{2}{*}{ Sources } \\
\hline & $18 \mathrm{~S}$ & $28 S$ & $\mathrm{COI}$ & \\
\hline \multicolumn{5}{|l|}{ Ingroup (Dinophilidae) } \\
\hline Dinophilus gyrociliatus Schmidt, 1857 & AF412805 & - & - & Struck et al. (2002) \\
\hline Dinophilus sp. & FJ200245 & FJ200246 & - & Worsaae and Rouse (2008) \\
\hline Trilobodrilus axi Westheide, 1967 & AF412806 & AY894292 & - & Struck et al. $(2002,2005)$ \\
\hline Trilobodrilus heideri Remane, 1925 & AF412807 & AY732231 & - & Struck et al. $(2002,2005)$ \\
\hline Trilobodrilus itoi sp. nov. & DRA001682 & DRA001682 & AB924371 & Present study \\
\hline Trilobodrilus nipponicus Uchida and Okuda, 1943 & LC009446 & LC009447 & LC009445 & Present study \\
\hline \multicolumn{5}{|l|}{ Outgroup (Dorvilleidae) } \\
\hline Dorvillea erucaeformis (Malmgren, 1865) & AY176285 & AY838859 & AY838868 & Worsaae et al. (2005); Struck et al. (2006) \\
\hline Exallopus jumarsi Blake, 1985 & - & - & JQ310755 & Wiklund et al. (unpubl.) \\
\hline Iphitime hartmanae Kirkegaard, 1977 & - & - & GQ415472 & Wiklund et al. (2009) \\
\hline Microdorvillea sp. & AY527051 & - & - & Struck (unpubl.) \\
\hline Ophryotrocha labronica La Greca and Bacci, 1962 & AY838855 & DQ790047 & AY838874 & Struck et al. $(2006,2007)$ \\
\hline Parougia eliasoni (Oug, 1978) & - & DQ790053 & GQ415489 & Struck et al. (2007); Wiklund et al. (2009) \\
\hline Pettiboneia urciensis Campoy and San Martin, 1980 & $\mathrm{AF} 412801$ & - & - & Struck et al. (2002) \\
\hline Protodorvillea kefersteini (McIntosh, 1869) & AF412799 & AY732230 & KF808171 & Struck et al. (2002, 2005); Aylagas et al. (2014) \\
\hline Schistomeringos longicornis (Ehlers, 1901) & - & HM473268 & HM473662 & Carr (unpubl.) \\
\hline \multicolumn{5}{|l|}{ Outgroup (others) } \\
\hline Cirratulus spectabilis (Kinberg, 1866) & AY708536 & DQ790029 & - & Burnette et al. (2005); Struck et al. (2007) \\
\hline Diurodrilus subterraneus Remane, 1934 & KC790349 & KC790349 & KC790350 & Golombeck et al. (2013) \\
\hline Eunice sp. & AF412791 & AY732229 & - & Struck et al. $(2002,2005)$ \\
\hline Eurythoe complanata (Pallas, 1766) & AY364851 & AY364849 & JN086548 & Jördens et al. (2004); Borda et al. (2012) \\
\hline Nereis vexillosa Grube, 1851 & DQ790083 & DQ790043 & HM473512 & Struck et al. (2007); Carr et al. (2011) \\
\hline Pectinaria gouldii (Verrill, 1873) & DQ790091 & DQ790054 & FJ976040 & Struck et al. (2007); Zhong et al. (unpubl.) \\
\hline Sipunculus nudus Linnaeus, 1766 & DQ300006 & DQ300048 & DQ300162 & Schulze et al. (2007) \\
\hline
\end{tabular}

(lambda) $=24$. Alignment-ambiguous regions were removed by using BMGE v. 1.1 (Criscuolo and Gribaldo, 2010); the $18 \mathrm{~S}$ and $28 \mathrm{~S}$ alignments were processed with the "-t DNA" option, and COI with the "-t CODON" option. The lengths of the resulting sequence alignments were $1535 \mathrm{nt}(18 \mathrm{~S}), 1735 \mathrm{nt}(28 \mathrm{~S})$, and $645 \mathrm{nt}$ (COI); the genes were concatenated for phylogenetic analyses by using MEGA ver. 5.2.

The ML analysis was conducted in RAxML ver. 8 (Stamatakis, 2014) under the GTR+G model; for $18 S$ and $28 S$, the data were partitioned by gene; for $\mathrm{COI}$ by codon position. Nodal support values were estimated by bootstrapping with 1000 pseudoreplicates. RAxML was called as follows (except the options for input and output file names, as well as the partition file name): raxmlHPCPTHREADS-AVX -T 5 -f a $-x 12345$-p 12345 -\#1000 -m GTR GAMMA.

Bayesian inference was conducted by using MrBayes ver. 3.2.3 (Ronquist and Huelsenbeck, 2003; Altekar et al., 2004), with two independent Metropolis-coupled analyses, each using four Markov chains of 1,000,000 generations. Trees were sampled every 100 generations. Run convergence was assessed by using Tracer ver. 1.6 (Rambaut et al., 2014). For BI, jModeltest2 (Darriba et al., 2012) was used to determine the most suitable substitution model for each gene partition under the Bayesian information criterion, with the following settings: number of substitution schemes $=3$; including models with equal/unequal base frequencies $(+\mathrm{F})$; including models with/without a proportion of invariable sites $(+\mathrm{l})$; including models with/without rate variation among sites $(+G)(n C a t=4)$; optimized free parameters $(K)=$ substitution parameters +29 branch lengths + topology; base tree for likelihood calculations = ML tree; tree topology search operation $=\mathrm{NNI}$. The optimal models were $\mathrm{K} 80+\mathrm{I}+\mathrm{G}$ for $18 \mathrm{~S}, \mathrm{GTR}+\mathrm{G}$ for $28 \mathrm{~S}$, and $\mathrm{GTR}+\mathrm{I}+\mathrm{G}$ for $\mathrm{COI}$.

Kimura (1980) two-parameter (K2P) genetic distances were calculated by using MEGA ver. 5.2.

\section{RESULTS}

Taxonomy

Trilobodrilus itoi sp. nov.

(Fig. 3)

Material examined. Syntypes, ZIHU 4885, 17 specimens, Au-coated and mounted on SEM stub, collected by M. Ikoma and H. Kajihara, 15 January 2012, Ishikari Beach

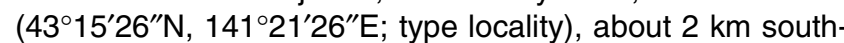
southwest from the mouth of the Ishikari River, Hokkaido, northern Japan; from surface layer of sediment (medium sand) to about $10 \mathrm{~cm}$ depth at water's edge. Eleven specimens, same locality as for syntypes, collected by M. I., 30 September 2013, observed alive by light microscopy, destroyed after observation except for two non-type specimens: ZIHU 4886 (fixed in 10\% formalin-seawater, mounted in glycerine on a glass slide, with the edge of the coverslip sealed with Canada balsam) and ZIHU 4887 (fixed in Bouin's fluid, mounted in the same manner as ZIHU 4886). More than 50 specimens collected sporadically at the type locality from 29 October 2012 to 30 September 2013, all destroyed after observation by light microscopy and DNA extraction.

Sequences. The following sequences were determined by standard sequencing from a single, non-type specimen collected on 17 December 2012, for which no morphological voucher remains: COI, AB924371 (658 nt, coding 219 aa); $18 S$ rRNA, AB924372 (1714 nt); 28S rRNA, AB924373 (1120 nt). In addition, 75,340 reads (equivalent to $18.6 \mathrm{M}$ bases) by new-generation sequencing from eight specimens 

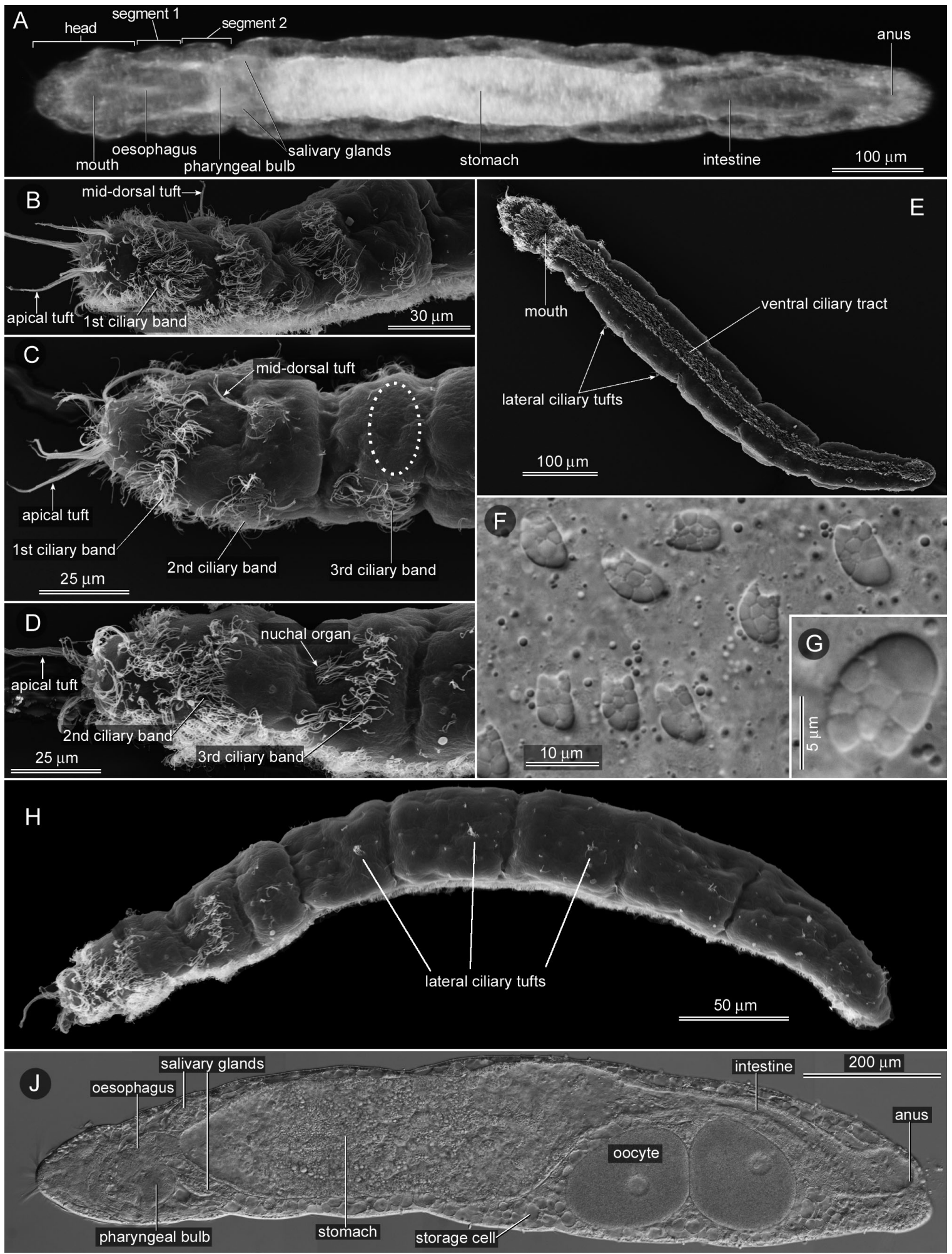

Fig. 3. Trilobodrilus itoi sp. nov. (A, F, G, J) Living, non-type specimens, destroyed by compression during observation; (B-E, H) SEM images, syntype, ZIHU 4885. (A) Anaesthetized whole specimen, photographed under dissecting microscope. (B) Head, front-lateral view. (C) Head, dorso-lateral view; dotted circle indicates wide gap in third ciliary band. (D) Head, lateral view. (E) Whole body, ventral view. (F) Photomicrograph of epidermal inclusions. (G) Magnification of epidermal inclusion. (H) Whole body, lateral view. (J) Photomicrograph of whole body.

in all, collected on 30 September 2013, have been deposited in the DDBJ Sequence Read Archive under accession number DRA001682. The complete $18 \mathrm{~S}$ sequence with parts of the ETS and ITS regions (3463 nt), as well as partial $28 \mathrm{~S}$ sequences including part of the ITS region (4620 nt), both assembled from DRA001682, are available as Supple- 
mentary Files S1 and S2, respectively.

Diagnosis. Trilobodrilus with second ciliary band incomplete dorsally, where single mid-dorsal ciliary tuft is present; third ciliary band dorsally discontinuous, with large gap.

Description. Body $0.9-1.3 \mathrm{~mm}$ long, $0.08-0.12 \mathrm{~mm}$ wide $(n=11)$; colorless, translucent; stomach light yellow; salivary glands opaque white, sometimes tinged with green (Fig. 3A); oocytes cream white. Head with four apical ciliary tufts on anterior end, arranged dorsally and ventrally on both sides (Fig. 3B), as in congeners. Three ciliary bands present anteriorly (Fig. 3B-D); first band completely encircling head near tip (Fig. 3B, C); second band situated just anterior to mouth, dorsally discontinuous (Fig. 3C); third band post-oral on segment 1 , dorsally discontinuous, with wide gap (Fig. 3C). Single, long, mid-dorsal ciliary tuft in gapped portion of second band, oriented slightly anteriorly (Fig. 3B, C). Pair of nuchal organs in segment 1 , one on each side, just anterior to third ciliary band (Fig. 3D). Small, short ciliary tufts distributed sporadically on sides of body (Fig. 3E, H). In anaesthetized and fixed conditions, apparently 6-7 segments (except pygidium), although segmental boundaries posterior to segment 2 obscure; pygidium with unclear boundary (Fig. 3A, E, $\mathrm{H}$ ). Pair of salivary glands (Fig. $3 \mathrm{~A}, \mathrm{~J}$ ) between segments 2 and 3 . Width of central ciliary tract (Fig. 3E) about $40 \%$ (35$44 \%, n=4$ ) of body diameter in middle of body. Epidermal inclusions highly variable in shape, mostly elliptical, up to $7 \times 12 \mu \mathrm{m}$ in size (Fig. 3F, G); spherules 3-22 (mostly 7-8) in number ( $n=86$, five specimens) (see below "Epidermal inclusions"). Spindle glands not found (Fig. 3F). No mature male found. Females contained up to two oocytes, each up to $150 \mu \mathrm{m}$ in diameter, arranged in tandem beneath intestine (Fig. 3J); "storage cells" or "coelenchyme" of Fransen (1980, fig. $4 \mathrm{~A})$, up to $30 \mu \mathrm{m}$ in diameter, packed within coelom in mature females (Fig. 3J). Mature individuals with oocytes found in September and October.

Remarks. Trilobodrilus itoi differs from congeners, except for $T$. nipponicus, in having a mid-dorsal ciliary tuft in the gapped portion of the second ciliary band on the head (Table 3). Trilobodrilus itoi differs from $T$. nipponicus in having the third ciliary band (on the first body segment) discontinuous dorsally (vs continuous in $T$. nipponicus), and the ventral ciliary tract is narrow, about $40 \%$ of body width (vs wide, about $45 \%$ in $T$. nipponicus).

Ecology. At Ishikari Beach, T. itoi appeared to be narrowly restricted to the swash zone; none were found land- ward in subsurface water. Densities were locally variable; in calm sea conditions, up to 20 individuals were collected per $300 \mathrm{ml}$ of sand. The salinity during the sampling period was generally 30; the water temperature was $12^{\circ} \mathrm{C}$ on 29 October 2012 and $4^{\circ} \mathrm{C}$ on 17 December 2012. Itô (1985) found the sediment grain size at the site ( $\varphi$ scale; Krumbein, 1937) to be 1.2-1.7. Animals that co-occurred in the habitat included proseriate flatworms (one of which was Archotoplana yamadai Tajika, 1983); harpacticoid copepods (Arenopontia ishikariana Itô, 1968 and Leptastacus japonicus Itô, 1968); nematodes (genera Axonolaimus, Bathylaimus, Enoploides, Enoplolaimus, Epacanthion, Epsilonema, Mesacanthion, Metoncholaimus, Neochromadora, Oncholaimus, Parasaveljevia, Rhynchonema, Theristus, and Trissonchulus) (D. Shimada, pers. comm.); the non-interstitial gammarid amphipod Anisogammarus pugettensis (Dana, 1853) (cf. Hoshide, 1971); and the mysid Archaeomysis articulata Hanamura, 1997 (cf. Hanamura, 1999). With sporadic water changes, individuals of $T$. itoi were able to survive for more than a month without feeding in a Petri dish placed in an incubator at $12^{\circ} \mathrm{C}$.

Etymology. The specific name, a noun in the genitive case, is in honor of Dr Tatsunori Itô (1945-1990), a Japanese meiobenthologist and crustacean systematist, whose handbook for the general public, Organisms in Sand Interstices (Itô, 1985), influenced several successive generations in Japan. Ishikari Beach, the type locality, was one of Itô's primary research sites early in his career (e.g., Itô, 1970).

Trilobodrilus nipponicus Uchida and Okuda, 1943 (Fig. 4)

Trilobodrilus nipponicus Uchida and Okuda, 1943, p. 301, figs. 1,2 .

?Trilobodrilus nipponicus: Wieser (1957), p. 284, fig. 4; Chandrasekhara Rao and Ganapati (1968), p. 28, fig. 5.

Material examined. ZIHU 4946, 22 specimens, Aucoated and mounted on three SEM stubs, collected on a narrow beach about $50 \mathrm{~m}$ long at the base of a steep cliff near Cape Aikappu, Akkeshi, Hokkaido $\left(43^{\circ} 00^{\prime} 58^{\prime \prime} \mathrm{N}\right.$, $144^{\circ} 50^{\prime} 02^{\prime \prime}$ ) by M. Ikoma, S. F. Hiruta, and H. Kajihara, 23 September 2014. In addition, one specimen examined alive with light microscopy was destroyed after observation, and four other specimens were used for DNA extraction.

Sequences. The following sequences were determined

Table 3. Morphological characters and their states in the six species in Trilobodrilus.

\begin{tabular}{|c|c|c|c|c|c|c|c|c|c|c|c|c|}
\hline Species & $\begin{array}{l}\text { Body } \\
\text { length } \\
(\mathrm{mm})\end{array}$ & $\begin{array}{l}\text { Body } \\
\text { width } \\
(\mathrm{mm})\end{array}$ & $\begin{array}{l}\text { Number of } \\
\text { mid-dorsal } \\
\text { tuft on 2nd } \\
\text { ciliary band }\end{array}$ & $\begin{array}{c}\text { 3rd ciliary } \\
\text { band dorsally } \\
\text { continuous } \\
(+) \text { or not }(-)\end{array}$ & $\begin{array}{c}\text { Size of } \\
\text { epidermal } \\
\text { inclusions } \\
(\mu \mathrm{m})\end{array}$ & $\begin{array}{l}\text { Number of } \\
\text { spherules per } \\
\text { envelope }\end{array}$ & $\begin{array}{l}\text { Mean ratio of } \\
\text { length to width } \\
\text { of epidermal } \\
\text { inclusions }\end{array}$ & $\begin{array}{c}\text { Spindle } \\
\text { glands } \\
\text { present }(+) \\
\text { or absent }(-)\end{array}$ & $\begin{array}{l}\text { Stomach } \\
\text { color }\end{array}$ & Sex & Habitat & Source \\
\hline T. axi Westheide, 1967 & 1 & 0.1 & 0 & $-^{a}$ & $10 \times 15$ & $5-10$ & 1.81 & + & $?$ & dioecious & intertidal & I Westheide (1967) \\
\hline T. heideri Remane, 1925 & $1.5-1.9$ & $0.1-0.2$ & 0 & - & $?$ & $3-10$ & 1.41 & + & brown & dioecious & subtidal & $\begin{array}{l}\text { Remane (1925); } \\
\text { Westheide (1967) }\end{array}$ \\
\hline $\begin{array}{l}\text { T. hermaphroditus } \\
\text { Riser, } 1999\end{array}$ & $\sim 1.7$ & $\sim 0.22$ & 2 & $t^{\mathrm{b}}$ & $6 \times 9$ & $3-7$ & 1.42 & + & $\begin{array}{l}\text { greenish } \\
\text { brown }\end{array}$ & hermaphroditic & $\begin{array}{l}\text { intertidal/ } \\
\text { subtidal }\end{array}$ & Riser (1999) \\
\hline $\begin{array}{l}\text { T. indicus Chandrasekhara } \\
\text { Rao, } 1973\end{array}$ & $1.0-1.2$ & $0.1-0.12$ & 0 & + & 12 & $7-11$ & 2.42 & + & transparent? & dioecious & intertidal & $\begin{array}{l}\text { Chandrasekhara } \\
\text { Rao (1973) }\end{array}$ \\
\hline T. itoi sp. nov. & $0.9-1.3$ & $0.08-0.12$ & 1 & - & $7 \times 9$ & $3-22$ & 1.45 & - & yellowish & dioecious & intertidal & Present study \\
\hline $\begin{array}{l}\text { T. nipponicus Uchida } \\
\text { and Okuda, } 1943\end{array}$ & $0.7-1.4$ & $0.09-0.16$ & 1 & + & $5.5 \times 16$ & $9-13$ & 2.28 & - & $\begin{array}{l}\text { pale green } \\
\text { or yellowish } \\
\text { brown }\end{array}$ & dioecious & intertidal & $\begin{array}{l}\text { Uchida and } \\
\text { Okuda (1943); } \\
\text { present study }\end{array}$ \\
\hline
\end{tabular}

${ }^{\mathrm{a} C}$ Comprised of three rows, the 3 rd row present only on ventral side; ${ }^{b}$ horse-shoe shaped, not meeting ventral ciliary tract 

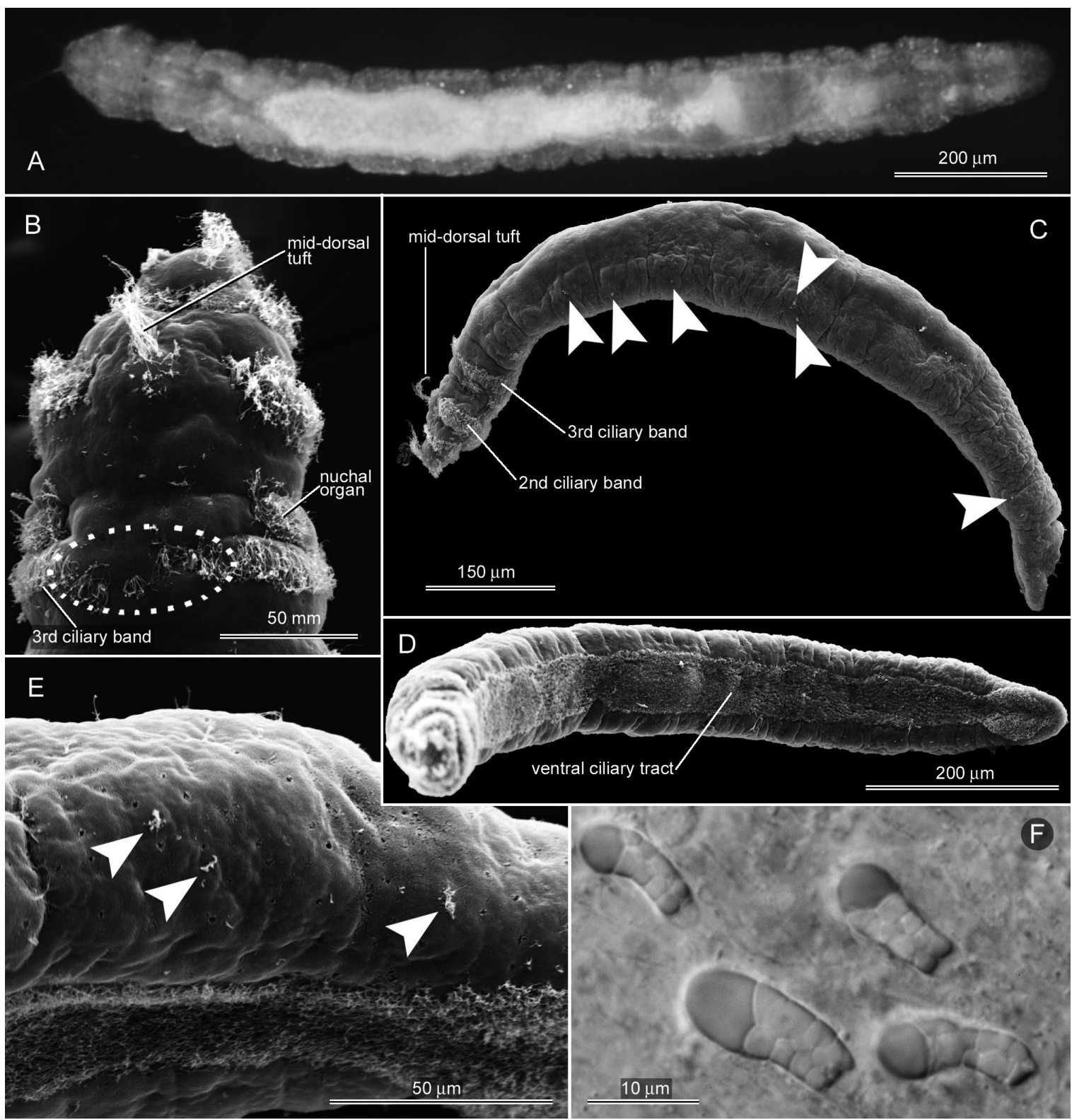

Fig. 4. Trilobodrilus nipponicus Uchida and Okuda, 1943. (A) ZIHU 4946, photographed alive under dissecting microscope before preparation for SEM. (B-E) ZIHU 4946, SEM images. (B) Head, dorsal view; dotted circle indicates dorsally continuous third ciliary band. (C) Lateral view of whole body; arrowheads indicate lateral ciliary tufts. (D) Ventral view of whole body. (E) Middle portion of body, ventrolateral view; arrowheads showing lateral ciliary tufts. (F) Photomicrograph of epidermal inclusions.

by standard sequencing from four specimens, for which no morphological vouchers remain: COI, LC009442-LC009445 (658 nt, coding 219 aa); 18S rRNA, LC009446 (from one specimen, $1784 \mathrm{nt}$ ); $28 \mathrm{~S}$ rRNA, LC009447 (from one specimen, $3596 \mathrm{nt})$.

Diagnosis. Trilobodrilus with second ciliary band dorsally incomplete, with single mid-dorsal tuft of cilia; third ciliary band nearly complete dorsally.

Description. Body 0.7-1.4 mm long, 0.09-0.16 mm wide $(n=23)$; colorless, translucent (Fig. 4A); stomach orange yellow; oocytes opaque white. Ciliary pattern same as for $T$. itoi, except: 1 ) third ciliary band continuous dorsally ( $n=14)$, although sometimes sparse $(n=7)$ (Fig. 4B), and 2) width of ventral ciliary tract about $52 \%(46-55 \%, n=4)$ of body width (Fig. 4D). Epidermal inclusions elongate, 11$16 \mu \mathrm{m}$ long, 3.5-5.5 $\mu \mathrm{m}$ wide, with 9-13 spherules per envelope (Fig. 4F); size ratio of major spherule to other spherules in each envelope appearing to be greater than that in $T$. itoi (Figs. 3G, 4F). Spindle glands not found.

Remarks. Our topotypic material agrees completely with the original description of $T$. nipponicus, except that lateral ciliary tufts were sparse in our material (Fig. 4C, E), rather than regularly arranged on each segment as described and illustrated by Uchida and Okuda (1943, fig. 1). Trilobodrilus nipponicus has been distinguished morphologically from congeners in having a single, mid-dorsal ciliary tuft on the head. Chandrasekhara Rao and Ganapati (1968) identified specimens from India as T. nipponicus 
because they had this type of mid-dorsal tuft. Because $T$. itoi also has a mid-dorsal tuft, the Indian form can no longer be positively identified as T. nipponicus. Rieger and Rieger (1975) also depicted a mid-dorsal tuft in an unidentified form collected from subtidal sand off Beaufort, North Carolina, Atlantic coast, USA; its identity should be investigated in future studies. A form from the Pacific coast near Seattle, USA, identified by Wieser (1957) as T. nipponicus lacks a mid-dorsal tuft; because the second ciliary band is continuous dorsally (Wieser, 1957, fig. 4), this form probably represents a different species.

Ecology. Although sediment-particle sizes were not measured, the sediment on the beach at Akkeshi appeared to be coarser than that at Ishikari Beach. Trilobodrilus nipponicus was extremely patchily distributed. We collected sediment at $\sim 20$ randomly chosen points along the beach in a zone a few meters landward or seaward from the water's edge, but detected $T$. nipponicus in only one sediment sample. We found 29 specimens in a $300 \mathrm{ml}$ of sediment sample, in which unidentified acoels, harpacticoids, and nematodes predominated; fragments of cirratulid branchial filaments were also found. Uchida and Okuda (1943) reported that "the Archiannelid, Saccocirrus major, the Rhabdocoelid Turbellarian, Thylacorhynchus sp. and some nemerteans" co-occurred with $T$. nipponicus. While we did observe saccocirrids, they did not appear to utilize the same microhabitat as $T$. nipponicus. An unidentified species of Proschizorhynchella (Kalyptorhynchia: Schizorhynchia) cooccurred at low frequency (K. Tamura pers. comm.). Nemerteans in the genus Cephalothrix were found at the beach, but no species in Ototyphlonemertes, an interstitial ribbonworm genus often found intertidally. We examined sediment on the northern and western coasts of Akkeshi Bay, and on two other beaches on the eastern coast (south of the type locality), but did not find Trilobodrilus. Sediments were gravelly on the northern coast, silty on the western coast, and composed of finer sand on the two southeastern beaches.

\section{Epidermal inclusions}

Spherules could be observed by light-microscopy when the animal was slightly squashed under a cover slip, but forceful squashing was necessary to count the number of spherules in a single envelope. After forceful squashing, however, the spherule(s) partly or entirely exuded from the envelope, especially near the edge of the body (Fig. 5). We

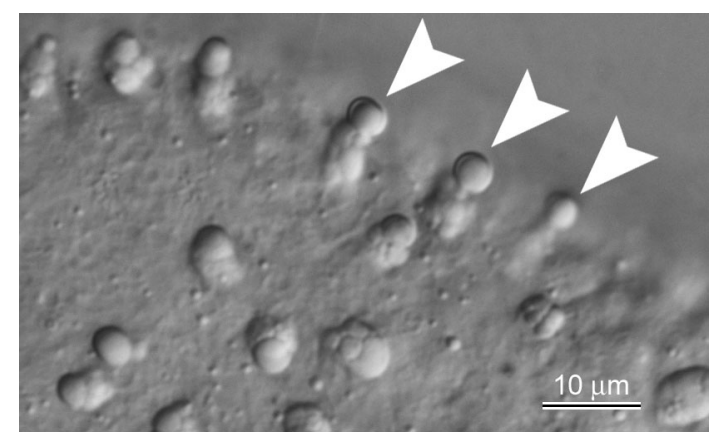

Fig. 5. Trilobodrilus itoi sp. nov., photomicrograph of epidermal inclusions near edge of body; arrowheads indicate major spherules appearing to be squeezed out of epidermis. eventually gave up counting the exact number of spherules in each envelope, because 1) smaller spherules below 0.2 $\mu \mathrm{m}$ in diameter (i.e., approaching the limit of the optical resolution for a $100 \times$ oil-immersion lens) occurred between larger spherules, and 2) the spherules were not arranged at the same focal depth, with the deeper portion obscured.

The mean value in the ratio of length to width of the epidermal inclusions among the five specimens of $T$. itoi ranged from 1.35 to 1.55 (Fig. 6A), with no significant differences among the five in variation $(P=0.13$ : Bartlett's test) or mean
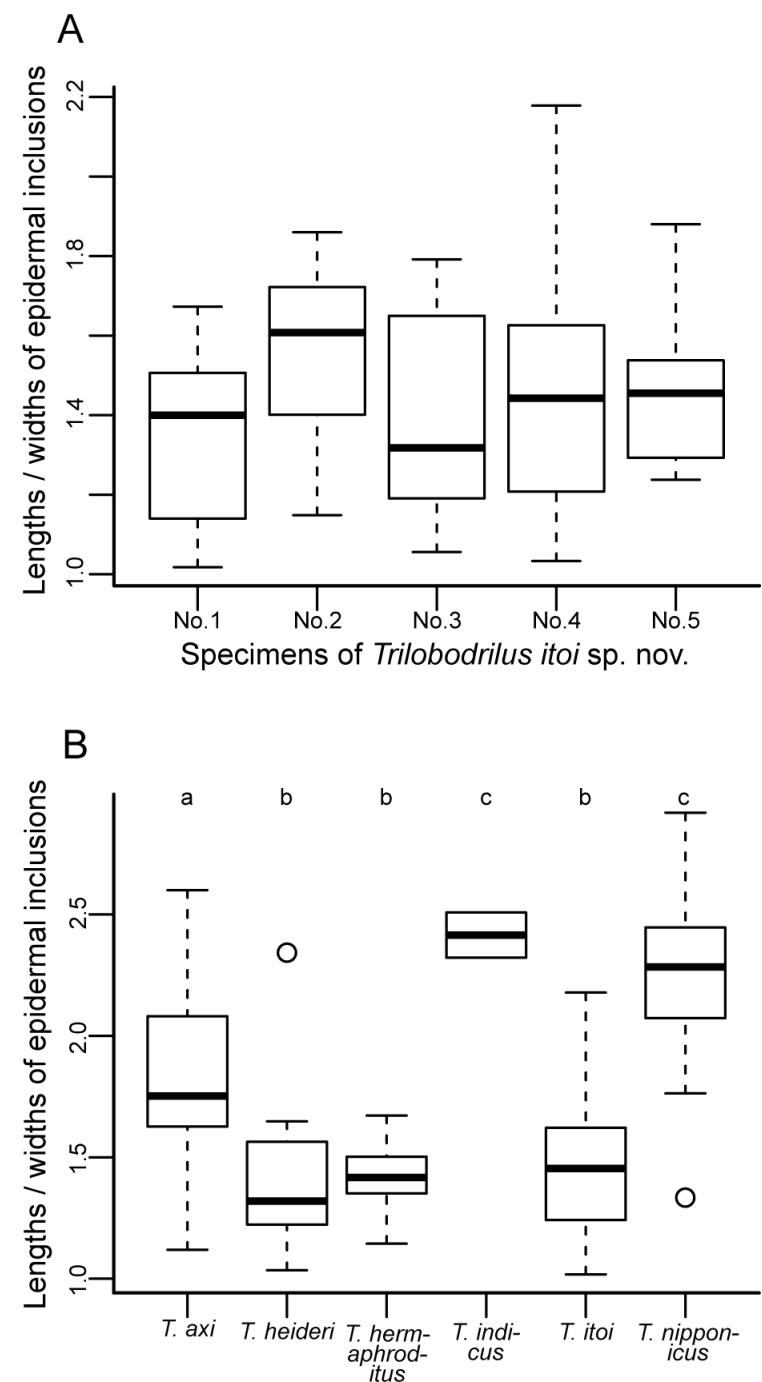

Fig. 6. Standard box-and-whisker plots of the length-width ratio of epidermal inclusions; the box encompasses the first and third quartiles; the thick horizontal bar within the box depicts the median; and whiskers depict the true minimum and maximum values, except where outliers (circles) greater than 1.5 times the interquartile range were identified. (A) Intraspecific variation in Trilobodrilus itoi sp. nov. among five specimens (specimen No. 1 was a mature, but tiny, female $0.9 \mathrm{~mm}$ in body length; Nos. 2-5 were immature specimens, 1.1-1.3 $\mathrm{mm}$ in body length). (B) Interspecific variation among six congeners; means with the same lower-case letter at the top of the graph are not significantly different based on Tukey's HSD test $(\alpha=$ 0.05). Data from the literature: $T$. axi and T. heideri, Westheide (1967); T. indicus, Chandrasekhara Rao (1973); T. hermaphroditus, Riser (1999). 
( $P=0.30-0.99:$ Tukey's HSD test).

Significant differences in variation were observed among the six species of Trilobodrilus when two outliers (one each in $T$. heideri and $T$. nipponicus) were included ( $P=0.0038:$ Bartlett's test). Excluding these outliers resulted in no significance $(P=0.014, \alpha=0.01)$; the greater $P$ value was likely due to the small sample size in $T$. indicus $(n=2)$. Excluding the outliers, three groups of mean lengthwidth ratio values were evident: i) $T$. axi (1.81); ii) $T$. heideri (1.41), T. hermaphroditus (1.42), and T. itoi (1.45); and iii) T. indicus (2.42) and T. nipponicus (2.28) (Fig. 6B).

\section{Phylogeny and genetic distance}

In the best $M L$ tree $(\operatorname{InL}=-23774.622593)$ (Fig. 7) and $\mathrm{BI}$ tree (Supplementary Fig. S1), Dinophilidae is monophyletic, with $97 \%$ bootsrtap frequency (BF) and 1.00 posterior probability (PP). Within Dinophilidae, $T$. itoi and $T$. nipponicus form a clade ( $97 \%$ BF, $1.00 \mathrm{PP})$, as do the two European species, $T$. axi and T. heideri (96\% BF, $1.00 \mathrm{PP})$. These two clades together comprise a monophyletic group (67\% BF, 0.98 PP). Dinophilus sp. sensu Worsaae and Rouse (2008) is the sister group to Trilobodrilus spp. (97\% BF, 1.00 PP), and Dinophilus gyrociliatus Schmidt, 1857, is the sister group to all other species in Dinophilidae (97\% BF, 1.00 PP). Our results thus refute the suggestion (Westheide, 1967) that, based on morphological similarity, T. heideri might be more closely related to $T$. nipponicus than to $T$. axi .

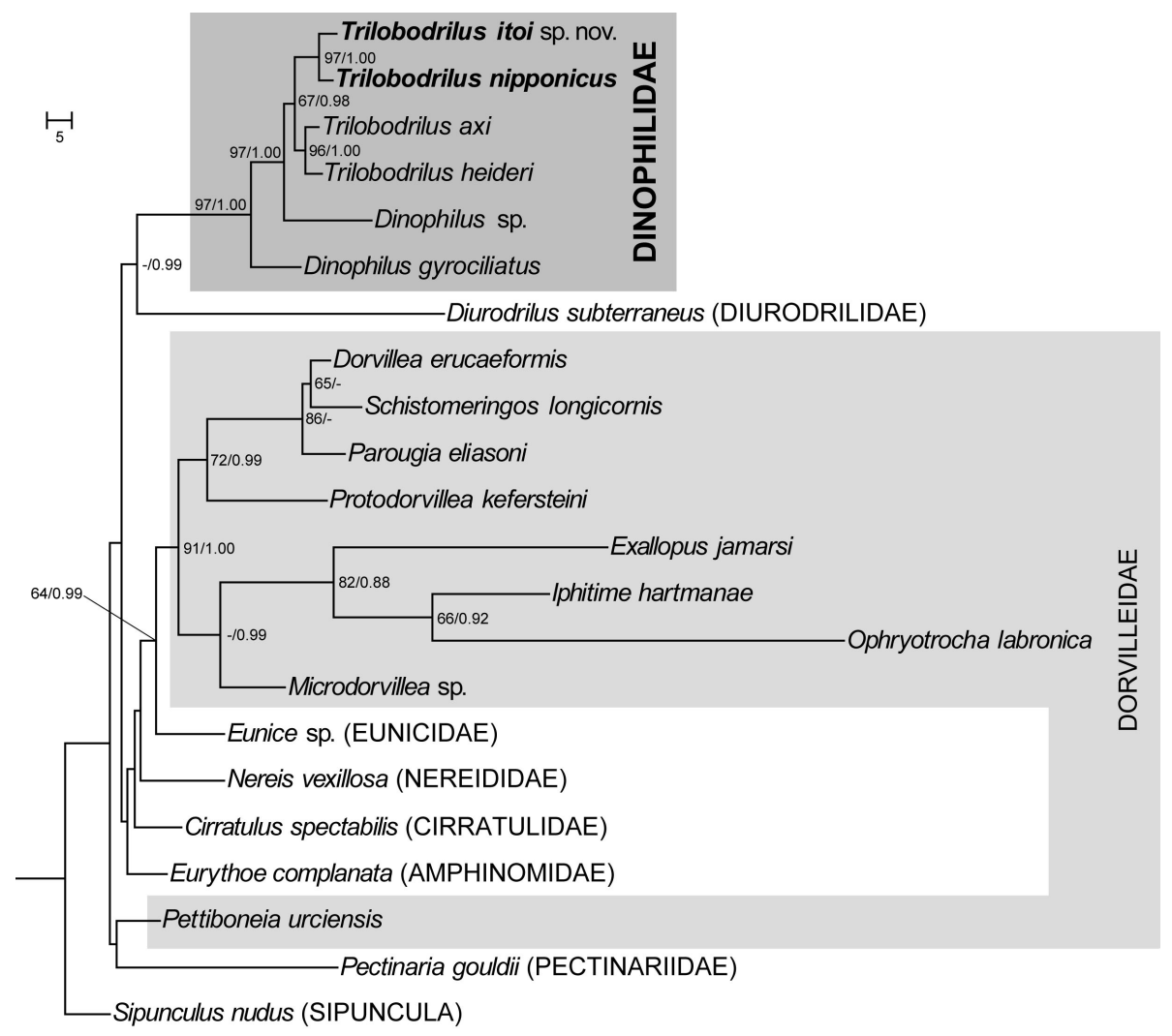

Fig. 7. Phylogenetic tree resulting from maximum-likelihood analysis based on combined COI, 18S, and 28S rRNA gene sequences ( $\ln L=-23774.622593)$. Numbers near nodes indicate maximum-likelihood bootstrap support values in percent $(>60 \%)$ and posterior probability from Bayesian inference $(>0.90)$, respectively.
Our study corroborated that of Struck et al. $(2002,2005)$ in failing to support the morphology-based hypothesis (Eibye-Jacobsen and Kristensen, 1994) of a close relationship between Dinophilidae and Dorvilleidae. All the dorvilleids included in our analyses (except for Pettiboneia urciensis Campoy and San Martin, 1980) formed a clade (91\% BF, $1.00 \mathrm{PP})$ that was the sister group to Eunice sp. $(64 \% \mathrm{BF}$, $0.99 \mathrm{PP})$.

The interspecific K2P genetic distance for $\mathrm{COI}$ based on one specimen of $T$. ito $i$ and four of $T$. nipponicus was 22.5$22.7 \%$. These values are comparable with interspecific K2P distances for $\mathrm{COI}$ in other genera of interstitial polychaetes, e.g., 23.6-27.0\% among six species in Protodrilus ( $\mathrm{Di}$ Domenico et al., 2013; Martínes et al., 2013), and in genera of non-interstitial annelids, e.g., an average of $26.2 \%$ in Hydroides (Sun et al., 2012) and 19.2-26.2\% among three species of Glycera (Schüller, 2011).

\section{DISCUSSION}

We discovered two species of Trilobodrilus along the shores of Hokkaido Island, one at Ishikari Beach on the west coast, and the other in Akkeshi Bay on the east, with the two localities $1050 \mathrm{~km}$ (northward course) and $1230 \mathrm{~km}$ (southward course) apart in along-shore distances (Fig. 1). While we did not record precise physical/geological data for the habitat such as granulometry, the two beaches do differ in physical properties. In beach morphodynamics (Wright and Short, 1984), Ishikari Beach is the intermediate to dissipative type, with finer sand, while the beach in Akkeshi Bay is more or less reflective, with coarser sand. Our sampling site on Ishikari Beach, which is a stretch of sandy shore $25 \mathrm{~km}$ long, is $2 \mathrm{~km}$ from a river mouth, while the small, unnamed beach in Akkeshi Bay, roughly $50 \mathrm{~m}$ long, appeared to receive a continuous input of organic detritus from the nearby rocky and particulate shores that are rich in macroalgae and sea grasses. In addition to differences in the physical properties between the two beaches, they are under the influence of different ocean currents: the warm Tsushima Current flowing north off Ishikari Beach on the Sea of Japan, and the cold Oyashio Current flowing south outside Akkeshi Bay on the Pacific Ocean (Fig. 1).

Overall, the distribution of the two species appeared to be quite restricted, differing widely in scales ranging from microhabitat to the geographical and oceanographic levels. In this context, the putative wide distribution of $T$. nipponicus across the Indo-Pacific (Wieser, 1957; Chandrasekhara Rao and Ganapati, 1968) is likely the result 
of misidentification (see Remarks above), as opponents of the "everything is everywhere" hypothesis (for review, De Wit and Bouvier, 2006; Fontaneto and Brodie, 2011; Williams, 2011) have put forward (e.g., Coleman, 2002; Foissner, 2006; Taylor et al., 2006). The species in Trilobodrilus so far investigated are all direct developers lacking a planktonic larval phase (Uchida and Okuda, 1943; Ax, 1968), which suggests relatively low dispersal ability, which in turn may be related to the restricted distributions observed in this study. The phylogeographic pattern in our phylogeny, in which the two Japanese species comprise the sister group to a clade containing the two European forms, may also be related to the poor dispersal potential in Trilobodrilus.

Species in Trilobodrilus were thought to be morphologically similar, distinguished by "the number of body segments, structure of head and pygidium, distribution of ciliary rings, lateral tufts of cilia, tactile bristles, structure of epidermal glands [sic], etc." (Chandrasekhara Rao, 1973), until the fourth congener ( $T$. indicus) was described. While the fifth species ( $T$. hermaphroditus) differs from all of its congeners in being hermaphroditic, Riser (1999) pointed out that the body segmentation can vary during specimen preparation (pressure under the cover slip, anaesthetization, and fixation), and other characters, such as the four anterior tactile bristles (ciliary tufts) on the tip of the head, are present in all congeners and thus have little value in distinguishing between species. With regard to the epidermal inclusions, our observations indicated that 1) counting the number of spherules per envelope is impractical because there can be a number of extremely small $(<0.2 \mu \mathrm{m})$ spherules at different focus depths, but 2) the mean length-width ratio (L/W) may be of taxonomic utility, with three groups of species having been detected: $T$. indicus and $T$. nipponicus (elongate type, L/W > 2.0); T. axi (medium type, $1.5 \leq \mathrm{L} / \mathrm{W} \leq 2.0$ ); and $T$. heideri, T. hermaphroditus, and T. itoi (oval type, L/W < 1.5).

The effectiveness of incorporating DNA data in studies of meiofaunal taxonomy has become apparent for many taxa, including Nemertodermatida (Meyer-Wachsmuth et al., 2014), Proseriata (Casu and Curini-Galletti, 2006; Scarpa et al., 2015), Gastrotricha (Kieneke et al., 2012), Nemertea (Tulchinsky et al., 2012; Leasi and Norenburg, 2014), Annelida (Di Domenico et al., 2014c; Martínez et al., 2014), and Rotifera (Fontaneto, 2014). While our SEM observations revealed some subtle differences in ciliation pattern between $T$. itoi and $T$. nipponicus, before comparing their DNA sequences we were uncertain whether these two represented different species. DNA taxonomy (e.g., Fontaneto et al., 2009), or "turbo-taxonomy"-an approach combining COI sequences, concise morphological descriptions, and high-resolution digital imaging (Butcher et al., 2012; Riedel et al., 2013) - will likely be essential in future studies to elucidate the diversity of these morphologically character-poor meiofauna, especially for material from areas previously not investigated.

\section{ACKNOWLEDGMENTS}

We thank Professor Matthew $\mathrm{H}$. Dick for reviewing and editing the manuscript; two anonymous reviewers for constructive criticism on an earlier version of the manuscript; Professor/Director Masahiro Nakaoka and other staff at the Akkeshi Marine Station for providing facilities; Naoya Takeda and Kohtaro Tamura for information on Kalyptorhynchia; Daisuke Shimada for information on nematodes; Shohei Yamauchi for help in collecting; Daisuke Shimada and Shinri Tomioka for assisting with SEM observation; and Keiichi Kakui for assisting with photography. This study was financially supported by JSPS KAKENHI Grant Numbers 23370038 and 2565013.

\section{REFERENCES}

Altekar G, Dwarkadas S, Huelsenbeck JP, Ronquist F (2004) Parallel Metropolis-coupled Markov chain Monte Carlo for Bayesian phylogenetic inference. Bioinformatics 20: 407-415

Ax P (1968) Das Fortpflanzungsverhalten von Trilobodrilus (Archiannelida, Dinophilidae). Mar Biol 1: 330-335

Aylagas E, Borja Á, Rodrígez-Ezpelata N (2014) Environmental status assessment using DNA metabarcoding: towards a genetics based marine biotic index (gAMBI). PLoS ONE 9: e90529 doi:10.1371/journal.pone.0090529

Bailey-Brock JH, Jouin-Toulmond C, Brock RE (2010) Protodrilidae (Annelida: Polychaeta) from the Hawaiian Islands and comparison with specimens from French Polynesia. Pac Sci 64: 463472

Blake JA (1985) Polychaeta from the vicinity of deep-sea geothermal vents in the eastern Pacific. I. Euphrosinidae, Phyllodocidae, Hesionidae, Nereididae, Glyceridae, Dorvilleidae, Orbiniidae, and Maldanidae. Bull Biol Soc Wash 6: 67-101

Boaden PJS (1963) Behaviour and distribution of the archiannelid Trilobodrilus heideri. JMBA UK 43: 239-250

Borda E, Kudenov JD, Bienhold C, Rouse G (2012) Towards a revised Amphinomidae (Annelida, Amphinomida): description and affinities of a new genus and species from the Nile Deepsea Fan, Mediterranean Sea. Zool Scr 41: 307-325

Burnette AB, Struck TH, Halanych KM (2005) Holopelagic Poeobius meseres ("Poeobiidae," Annelida) is derived from benthic flabelligerid worms. Biol Bull 208: 213-220

Butcher BA, Smith MA, Sharkey MJ, Quicke DLJ (2012) A turbotaxonomic study of Thai Aleiodes (Aleiodes) and Aleiodes (Arcaleiodes) (Hymenoptera: Braconidae: Rogadinae) based largely on COI barcoded specimens, with rapid descriptions of 179 new species. Zootaxa 3457: 1-232

Campoy A, San Martin G (1980) Pettiboneia urciensis sp. n.: un nouveau Dorvilleidae (Polychètes: Errantes) de la Méditerranée. Cah Biol Mar 21: 201-207

Carr CM, Hardy SM, Brown TM, Macdonald TA, Hebert PD (2011) A tri-oceanic perspective: DNA barcoding reveals geographic structure and cryptic diversity in Canadian polychaetes. PLoS ONE 6: e22232 doi:10.1371/journal.pone.0022232

Casu M, Curini-Galletti M (2006) Genetic evidence for the existence of cryptic species in the mesopsammic flatworm Pseudomonocelis ophiocephala (Rhabditophora: Proseriata). Biol J Linn Soc 87: 553-576

Chandrasekhara Rao G (1973) Trilobodrilus indicus n. sp. (Dinophilidae, Archiannelida) from Andhra coast. Proc Indian Acad Sci Sect B 77: 101-108

Chandrasekhara Rao G, Ganapati PN (1968) On some archiannelids from the beach sands of Waltair Coast. Proc Indian Acad Sci Sect B 67: 24-30

Criscuolo A, Gribaldo S (2010) BMGE (block mapping and gathering with entropy): selection of phylogenetic informative regions from multiple sequence alignments. BMC Evol Biol 10: 210

Coleman AW (2002) Microbial eukaryote species. Science 297: 337

Curini-Galletti M, Artois T, Delogu V, De Smet WH, Fontaneto D, Jondelius $U$, et al. (2012) Patterns of diversity in soft-bodied meiofauna: dispersal ability and body size matter. PLoS ONE 7: e33801 doi:10.1371/journal.pone.0033801

Dana JD (1853) Crustacea. Part II. United States Exploring Expedition During the Years 1838, 1839, 1840, 1841, 1842 under the Command of Charles Wilkes, U.S.N., Vol 13. Sherman, 
Philadelphia, pp 689-1618

Darriba D, Taboada GL, Doallo R, Posada D (2012) jModelTest2: more models, new heuristics and parallel computing. Nat Methods 9: 772

De Wit R, Bouvier T (2006) 'Everything is everywhere, but, the environment selects'; what did Baas Becking and Beijerinck really say? Environ Microbiol 8: 755-758

Di Domenico M, Martínez A, Alimeida TCM, Martins MO, Worsaae K, Lana PC (2014a) Response of the meiofaunal annelid Saccocirrus pussicus (Saccocirridae) to sandy beach morphodynamics. Hydrobiologia 734: 1-16

Di Domenico M, Martínez A, Amaral ACZ, Lana P da C, Worsaae K (2014b) Saccocirridae (Annelida) from the southern and southeastern Brazilian coasts. Mar Biodiv 44: 313-325

Di Domenico M, Martínez A, Lana P da C, Worsaae K (2013) Protodrilus (Protodrilidae, Annelida) from the southern and southeastern Brazilian coasts. Helgol Mar Res 67: 733-748

Di Domenico M, Martínez A, Lana P, Worsaae K (2014c) Molecular and morphological phylogeny of Saccocirridae (Annelida) reveals two cosmopolitan clades with specific habitat preferences. Mol Phylogenet Evol 75: 202-218

Edgar RC (2004) MUSCLE: a multiple sequence alignmnet method with reduced time and space complexity. BMC Bioinfomatics 5: 113

Ehlers E (1901) Die Polychaeten des magellanischen und chilenischen Strandes. Ein faunistischer Versuch. Festschrift zur Feier des hundertfünfzigjährigen Bestehens des königlichen Gesellschaft der Wissenschaften zu Göttingen. Abteilungen der mathematisch-physikalischen Klasse. Weidmann, Berlin

Eibye-Jacobsen D, Kristensen RM (1994) A new genus and species of Dorvilleidae (Annelida, Polychaeta) from Bermuda, with a phylogenetic analysis of Dorvilleidae, Iphitimidae and Dinophilidae. Zool Scr 23: 107-131

Foissner W (2006) Biogeography and dispersal of microorganisms: a review emphasizing protists. Acta Protozool 45: 111-136

Folmer O, Black M, Hoeh W, Lutz R, Vrijenhoek R (1994) DNA primers for amplification of mitochondrial cytochrome $c$ oxidase subunit I from diverse metazoan invertebrates. Mol Mar Biol Biotech 3: 294-299

Fontaneto D (2014) Molecular phylogenies as a tool to understand diversity in rotifers. Int Rev Hydrobiol 99: 178-187

Fontaneto D, Brodie J (2011) Why biogeography of microorganisms? In "Biogeography of Microscopic Organisms: Is Everything Small Everywhere?" Ed by D Fontaneto, Cambridge University Press, Cambridge, pp 3-10

Fontaneto D, Kaya M, Hernioua EA, Barraclough TG (2009) Extreme levels of hidden diversity in microscopic animals (Rotifera) revealed by DNA taxonomy. Mol Phylogenet Evol 53: 182-189

Fransen ME (1980) Ultrastructure of coelomic organization in annelids. I. Archiannelids and other small polychaetes. Zoomorphologie 95: 235-249

Golombek A, Tobergte S, Nesnidal MP, Purschke G, Struck TH (2013) Mitochondrial genomes to the rescue-Diurodrilidae in the myzostomid trap. Mol Phylogenet Evol 68: 312-326

Grube AE (1851) Annulaten. In "Reise in den äussersten Norden und osten Siberiens während der Jahre 1843 und 1844 mit allerhöchster Genehmigung auf Veranstaltung der kaiserlichen Akademie der Wissenschaften zu St. Petersburg ausgeführt und in Verbindung mit vielen Gelehrten herausgegeben, Vol 2, Part 1" Ed by A Th von Middendorff, Kaiserlichen Akademie der Wissenschaften, St. Petersburg, pp 1-24

Hanamura Y (1997) Review of the taxonomy and biogeography of shallow-water mysids of the genus Archaeomysis (Crustacea: Mysidacea) in the North Pacific Ocean. J Nat Hist 31: 669-711

Hanamura $Y$ (1999) Seasonal abundance and life cycle of Archaeomysis articulata (Crustacea: Mysidacea) on a sandy beach of western Hokkaido, Japan. J Nat Hist 33: 1811-1830

Hoshide K (1971) Studies on gregarines from Japan II. Cephaloidophora anisogammari n. sp. and Cephaloidophora elongata n. sp. from amphipoda. J Fac Sci Hokkaido Univ Ser VI Zool 18: 186-192

Itô T (1968) Description and records of marine harpacticoid copepods from Hokkaido I. J Fac Sci Hokkaido Univ Ser VI Zool 16: 369-381

Itô T (1970) The study of interstitial fauna on Ishikari coast, Hokkaido. Benthos Res 1: 21-23 [in Japanese]

Itô T (1985) Organisms in Sand Interstices. Kaimeisha, Tokyo [in Japanese]

Jördens J, Struck T, Purschke G (2004) Phylogenetic inference regarding Parergodrilidae and Hrabeiella periglandulata ('Polychaeta', Annelida) based on 18S rDNA, 28S rDNA and COI sequences. J Zool Syst Evol Res 42: 270-280

Kieneke A, Martínez Arbizu PM, Fontaneto D (2012) Spatially structured populations with a low level of cryptic diversity in European marine Gastrotricha. Mol Ecol 21: 1239-1254

Kim C-G, Zhou H-Z, Imura Y, Tominaga O, Su Z-H, Osawa S (2000) Pattern of morphological diversification in the Leptocarabus ground beetles (Coleoptera: Carabidae) as deduced from mitochondrial ND5 gene and nuclear 28S rRNA sequences. Mol Biol Evol 17: 137-145

Kimura M (1980) A simple method for estimating evolutionary rates of base substitutions through comparative studies of nucleotide sequences. J Mol Evol 16: 111-120

Kinberg JGH (1866) Annulata nova. Ofv Ak Forh 22: 239-258

Kirkegaard JB (1977) A new species of Iphitime (Polychaeta: Iphitimidae) living under the tail of Hyas (Crustacea: Decapoda) in the Oslo Fjord. In "Essays on Polychaetous Annelids in Memory of Dr Olga Hartman" Ed by DJ Reich, K Fauchald, Allan Hancock Foundation, University of Southern California Press, Los Angeles, pp 199-209

Krumbein WC (1937) The sediments of Barataria Bay. J Sed Petrol 7: 3-17

Kvist S, Siddall ME (2013) Phylogenomics of Annelida revised: a cladistic approach using genome-wide expressed sequence tag data mining and examining the effects of missing data. Cladistics 29: 435-448

La Greca M, Bacci G (1962) Una nuova specie di Ophryotrocha delle coste tirreniche (Annelida, Polychaeta). Bolletin Zool 29: $7-18$

Leasi F, Norenburg JL (2014) The necessity of DNA taxonomy to reveal cryptic diversity and spatial distribution of meiofauna, with a focus on Nemertea. PLoS ONE 9: e104385 doi:10.1371/ journal.pone.0104385

Linnaeus C (1766) Systema naturae per regna tria naturae, secundum classes, ordines, genera, species, cum characteribus, differentiis, synonymis, locis, tomus I, editio duodecima, reformata. Salvius, Stockholm

Luan Y-X, Mallatt JM, Xie R-D, Yang Y-M, Yin W-Y (2005) The phylogenetic positions of three basal-hexapod group (Protura, Diplura, and Collembola) based on ribosomal RNA gene sequences. Mol Biol Evol 22: 1579-1592

Malmgren AJ (1865) Nordiska hafs-annulater. Ofv Ak Forh 22: 181192

Martínes A, Di Domenico M, Jörger K, Norenburg JL, Worsaae K (2013) Description of three new species of Protodrilus (Annelida, Protodrilidae) from Central America. Mar Biol Res 9: 676-691

Martínez A, Di Domenico M, Rouse GW, Worsaae K (2014) Phylogeny and systematics of Protodrilidae (Annelida) inferred with total evidence analyses. Cladistics (early view) doi:10.1111/ cla.12089

McIntosh WC (1869) On the structure of British nemerteans, and some new British annelids. Tr R Soc Edinb 25: 305-433

Meyer-Wachsmuth I, Curini Galletti M, Jondelius U (2014) Hyper- 
cryptic marine meiofauna : species complexes in Nemertodermatida. PLoS ONE 9(9): e107688. doi:10.1371/journal.pone. 0107688

Nybakken JW, Higgins RP (2007) Intertidal meiobenthos. In "The Light and Smith Manual: Intertidal Invertebrates from Central California to Oregon, Completely Revised and Expanded" Ed by JT Carlton, University of California Press, Oakland, CA, pp $18-23$

Oug E (1978) New and lesser known Dorvilleidae (Annelida, Polychaeta) from Scandinavian and northeast American waters. Sarsia 63: 285-303

Pallas PS (1766) Miscellanea zoologica quibus novae imprimis atque obscurae animalium species describuntur et observationibus iconibusque illustrantur. Pieter van Cleef, The Hague

Palumbi SR (1996) Nucleic acids II: The polymerase chain reaction. In "Molecular Systematics, 2nd ed" Ed by DM Hills, C Moritz, BK Mable, Sinauer Associates, Sunderland, Massachusetts, pp 205-247

Park J-K, Ó Foighil D (2000) Sphaeriid and corbiculid clams represent separate heterodont bivalve radiations into freshwater environments. Mol Phylogenet Evol 14: 75-88

R Core Team (2014) R: A Language and Environment for Statistical Computing. R Foundation for Statistical Computing, Vienna, available at http://www.R-project.org

Rambaut A, Suchard MA, Xie W, Drummond AJ (2014) Tracer v 1.6, available at http://beast.bio.ed.ac.uk/Tracer

Rasband WS (1997-2014) ImageJ, U. S. National Institutes of Health, Bethesda, Maryland, USA, http://imagej.nih.gov/ij/

Read G (2014) Dinophilidae Remane, 1925. In "World Polychaeta Database" Ed by G Read, K Fauchald, World Register of Marine Species, http://www.marinespecies.org/aphia.php?p= taxdetails\&id=155089, accessed on 10 December 2014

Remane A (1925) Diagnosen neuer Archianneliden. Zool Anz 65: $15-17$

Remane A (1934) Diurodrilus subterraneus nov. spec., ein Archiannelide aus dem Küstengrundwasser. Schr Ver Schleswig-Holst 20: 479

Riedel A, Sagata K, Suhardjono YR, Tänzler R, Balke M (2013) Integrative taxonomy on the fast track-towards more sustainability in biodiversity research. Front Zool 10: 15

Rieger MM, Rieger GE (1975) Fine structure of the pharyngeal bulb in Trilobodrilus and its phylogenetic significance within Archiannelida. Tissue Cell 7: 267-279

Riser NW (1999) Description of a new species of dinophilid polychaete, with observations on other dinophilids and interstitial polychaetes in New England. Northeast Nat 6: 211-220

Ronquist F, Huelsenbeck JP (2003) MrBayes 3: Bayesian phylogenetic inference under mixed models. Bioinformatics 19: 15721574

Rousset V, Pleijel F, Rouse GW, Erséus C, Siddall ME (2007) A molecular phylogeny of annelids. Cladistics 23: 41-63

Rundell R, Leander BS (2010) Masters of miniaturization: convergent evolution among interstitial eukaryotes. BioEssays 32: 430-437

Scarpa F, Cossu P, Sanna D, Lai T, Norenburg JL, Curini-Galletti M, et al. (2015) An 18S and 28S-based clock calibration for marine Proseriata (Platyhelminthes). J Exp Mar Biol Ecol 463: 22-31

Scharnofske P (1986) Ultrastructure of sperm morphology of Trilobodrilus axi and T. heideri (Dinophilidae, Polychaeta). Helgol Meeresunters 40: 419-430

Schmidt O (1857) Zur Kenntnis der Turbellaria Rhabdocoela und einiger anderer Würmer des Mittelmeeres. SB Ak Wien 23: 347-366

Schüller M (2011) Evidence for a role of bathymetry and emergence in speciation in the genus Glycera (Glyceridae, Polychaeta) from the deep Eastern Weddell Sea. Polar Biol 34: 549-564

Schulze A, Cutler EB, Giribet G (2007) Phylogeny of sipunculan worms: a combined analysis of four gene regions and morphology. Mol Phylogenet Evol 42: 171-192

Stamatakis A (2014) RAxML version 8: a tool for phylogenetic analysis and post-analysis of large phylogenies. Bioinformatics 30 : $1312-1313$

Struck TH (2006) Progenetic species in polychaetes (Annelida) and problems assessing their phylogenetic affiliation. Integr Comp Biol 46:558-568

Struck TH, Halanych KM, Purschke G (2005) Dinophilidae (Annelida) is most likely not a progenetic Eunicida: evidence from $18 \mathrm{~S}$ and 28S rDNA. Mol Phylogenet Evol 37: 619-623

Struck TH, Nesnidal MP, Purschke G, Halanych KM (2008) Detecting possibly saturated positions in $18 \mathrm{~S}$ and $28 \mathrm{~S}$ sequences and their influence on phylogenetic reconstruction of Annelida (Lophotrochozoa). Mol Phylogenet Evol 48: 628-645

Struck TH, Purschke G, Halanych KM (2006) Phylogeny of Eunicida (Annelida) and exploring data congruence using a partition addition bootstrap alteration (PABA) approach. Syst Biol 55: 120

Struck TH, Schult N, Kusen T, Hickman E, Bleidorn CB, McHugh D, et al. (2007) Annelid phylogeny and the status of Sipuncula and Echiura. BMC Evol Biol 7: 57 doi:10.1186/1471-2148-7-57

Struck TH, Westheide W, Purschke G (2002) Progenesis in Eunicida ("Polychaeta," Annelida)-separate evolutionary events? Evidence from molecular data. Mol Phylogenet Evol 25: 190-199

Sun Y, Kupriyanova EK, Qiu JW (2012) COI barcoding of Hydroides: a road from impossible to difficult. Invert Syst 26: 539-547

Tajika K-I (1983) Zwei neue interstitielle Turbellarien der Gattung Archotoplana (Proseriata, Otoplanidae) aus Hokkaido, Japan. J Fac Sci Hokkaido Univ Ser VI Zool 23: 179-194

Tamura K, Perterson D, Peterson N, Stecher G, Nei M, Kumar S (2011) MEGA5: molecular evolutionary genetics analysis using maximum likelihood, evolutionary distance, and maximum parsimony methods. Mol Biol Evol 28: 2731-2739

Taylor JW, Turner E, Townsend JP, Dettman JR, Jacobson D (2006) Eukaryotic microbes, species recognition and the geographic limits of species: examples from the kingdom Fungi. Phil Trans Roy Soc B 361: 1947-1963

Tulchinsky AY, Norenburg JL, Turbeville JM (2012) Phylogeography of the marine interstitial nemertean Ototyphlonemertes parmula (Nemertea, Hoplonemertea) reveals cryptic diversity and high dispersal potential. Mar Biol 159: 661-674

Uchida T, Okuda S (1943) A new species of Archiannelida, Trilobodrilus nipponicus n. sp. J Fac Sci Hokkaido Imp Univ Ser VI Zool 8: 301-305

Verrill AE (1873) Report upon the invertebrate animals of Vineyard Sound and the adjacent waters, with an account of the physical characters of the region. In "Report on the Condition of the Sea Fisheries of the South Coast of New England in 1871 and 1872" Ed by SF Baird, Government Printing Office, Washington DC, pp 295-778

Weigert A, Helm C, Meyer M, Nickel B, Arendt D, Hausdorf B, et al. (2014) Illuminating the base of the annelid tree using transcriptomics. Mol Biol Evol 31: 1391-1401

Westheide W (1967) Die Gattung Trilobodrilus (Archiannelida, Polychaeta) von der deutschen Nordseeküste. Helgoländ wiss Meer 16: 207-215

Westheide W (1984) The concept of reproduction in polychaetes with small body size: adaptation in interstitial species. In "Polychaete Reproduction, Fortschritte der Zoologie, Vol 29" Ed by A Fischer, H-D Pfannenstiel, Gustav Fischer, New York, pp 265287

Westheide W (1987) Progenesis as a principle in meiofauna evolution. J Nat Hist 21: 843-854

Westheide W (2008) Polychaetes: Interstitial Families. Field Studies Council, Shrewsbury

Whiting MF, Carpenter JM, Wheeler QD, Wheeler WC (1997) The 
Strepsiptera problem: phylogeny of the holometabolous insect orders inferred from $18 S$ and $28 S$ ribosomal DNA sequences and morphology. Syst Biol 46: 1-68

Wieser W (1957) Archiannelids from the intertidal of Puget Sound. T Am Microsc Soc 76: 275-285

Wiklund H, Glover AG, Dahlgren TG (2009) Three new species of Ophryotrocha (Annelida: Dorvilleidae) from a whale-fall in the North-East Atlantic. Zootaxa 2228: 43-56

Williams DM (2011) Historical biogeography, microbial endemism and the role of classification: everything is endemic. In "Biogeography of Microscopic Organisms: Is Everything Small Everywhere?" Ed by D Fontaneto, Cambridge University Press, Cambridge, pp 11-31

Worsaae K, Nygren A, Rouse GW, Giribet G, Persson J, Sundberg $P$, et al. (2005) Phylogenetic position of Nerillidae and Aberranta (Polychaeta, Annelida), analysed by direct optimization of combined molecular and morphological data. Zool Scr 34(3): 313-328

Worsaae K, Kristensen RK (2005) Evolution of interstitial Polychaeta
(Annelida). Hydrobiologia 535-536: 319-340

Worsaae K, Rouse GW (2008) Is Diurodrilus an annelid? J Morphol 269: 1426-1455

Wright LD, Short AD (1984) Morphodynamic variability of surf zones and beaches: a synthesis. Mar Geol 56: 93-118

Yamaguchi S, Endo K (2003) Molecular phylogeny of Ostracoda (Crustacea) inferred from 18S ribosomal RNA sequences: implication for its origin and diversification. Mar Biol 143: 23-38

Yamanishi R (1983) Preliminary report on the fauna of interstitial polychaetes (Annelida) of Japan. Benthos Res 24: 41-48 (in Japanese)

Yamasaki H, Hiruta SF, Kajihara H (2013) Molecular phylogeny of kinorhynchs. Mol Phylogenet Evol 67: 303-310

Zrzavý J, Říha P, Piálek L, Janouškovec J (2009) Phylogeny of Annelida (Lophotrochozoa): total-evidence analysis of morphology and six genes. BMC Evolutionary Biology 9: 189 doi:10. 1186/1471-2148-9-189

(Received November 6, 2014 / Accepted April 7, 2015) 